\title{
Portable fiber-based fluorescence sensor for online assessment of transformer oil ageing
}

DOI:

10.1049/cp.2013.1196

Link to publication record in Manchester Research Explorer

\section{Citation for published version (APA):}

Yi, X., Chen, C., Wang, Z., Ozanyan, K., \& Jones, D. (2013). Portable fiber-based fluorescence sensor for online assessment of transformer oil ageing. In IET Conference Publications/IET Conf Publ (Vol. 2013) https://doi.org/10.1049/cp.2013.1196

\section{Published in:}

IET Conference Publications|IET Conf Publ

\section{Citing this paper}

Please note that where the full-text provided on Manchester Research Explorer is the Author Accepted Manuscript or Proof version this may differ from the final Published version. If citing, it is advised that you check and use the publisher's definitive version.

\section{General rights}

Copyright and moral rights for the publications made accessible in the Research Explorer are retained by the authors and/or other copyright owners and it is a condition of accessing publications that users recognise and abide by the legal requirements associated with these rights.

\section{Takedown policy}

If you believe that this document breaches copyright please refer to the University of Manchester's Takedown Procedures [http://man.ac.uk/04Y6Bo] or contact uml.scholarlycommunications@manchester.ac.uk providing relevant details, so we can investigate your claim.

\section{OPEN ACCESS}




\section{PORTABLE FIBER-BASED FLUORESCENCE SENSOR FOR ONLINE ASSESSMENT OF \\ TRANSFORMER OIL AGEING}

\author{
Xiao YI, Chen CHEN, Zhongdong WANG, Krikor OZANYAN \\ School of Electrical and Electronic Engineering, University of Manchester - UK
zhongdong.wang@ manchester.ac.uk / k.ozanyan@ manchester.ac.uk \\ zhongdong.wang@manchester.ac.uk / k.ozanyan@ manchester.ac.uk
}

\author{
Darren JONES \\ Electricity North West - UK \\ darren.jones@enwl.co.uk
}

\begin{abstract}
In smart grid, the penetration of electric vehicles would exacerbate the thermal ageing of transformer oil in distribution transformers. This would threaten the reliable and secure operation of distribution transformers and requires timely monitoring for oil conditions in distribution transformers. This work applies fluorescence spectroscopy to evaluate the ageing status of transformer oil. The fluorescence spectra were measured for the transformer oil samples thermally aged in laboratory. It is found that the ratio of the two peaks in fluorescence spectrum is well in line with traditional ageing parameters, including colour index and total acid number, which makes it feasible to apply the portable fibre-based fluorescent probe system in the online assessment of the ageing status of transformer oils.
\end{abstract}

\section{INTRODUCTION}

The development of smart grids raises attention to the insulation degradation of distribution transformers, because the increasing emergences of electric vehicles would elevate the thermal stress and worsen the thermal ageing of transformer oil [1-3]. This would threaten the reliable and secure operation of distribution transformers, increase the complexity of asset management for the large number of distribution transformers and require proper condition monitoring approaches for distribution transformers.

Fluorescence spectrum is sensitively related to the electronic state of the molecules; therefore, it can indirectly indicate the molecular changes during oil ageing process [4-12]. Recent developments in semiconductor diode sources bring down the cost of laser diodes and avail the deployment of cheap and portable fluorescence spectrum instrument [10-12].

This work applies fluorescence spectroscopy and fingerprinting to assess the ageing status of transformer oil, as a part of the goal towards the development of a reliable, cost-effective and field-deployable oil condition monitor for transformers. The fluorescence spectra of the transformer oil samples were measured after the samples were thermally aged in laboratory. It is found that the fluorescence spectrum characteristics are well correlated with traditional ageing parameters, including colour index and total acid number, which makes it feasible to apply this portable fibre-based fluorescent probe system for the ageing assessment of transformer oils.

\section{EXPERIMENTAL}

Nynas 10GBN, a naturally inhibited mineral oil, was subjected to the laboratory thermal ageing experiment which is a widely used approach to estimate the loss of life of the insulation. The samples were aged in an air circulating oven at $115^{\circ} \mathrm{C}$. In order to investigate the catalytic effects of copper, copper strips were added into some sample vials (to give a surface area of $9.6 \mathrm{~cm}^{2}$ per $500 \mathrm{ml}$ ) before the ageing experiment was conducted. To study the oxidation effect to thermal ageing, some sample vials were sealed by caps and the rest were left open. Separate $500 \mathrm{ml}$ samples were aged for each specified ageing time. After the ageing experiment finished, Lovibond PFX 880 Tintometer was used to measure the colour index according to ASTM D1500 scale [13]. The cuvette for colour index measurement has a $33 \mathrm{~mm}$ light path. In addition, Metrohm 848 Titrino plus was used to measure the total acid number of the samples. It was determined by titration of $5 \mathrm{~g}$ oil sample with potassium hydroxide $(\mathrm{KOH})$ solution.

\section{Fluorescence Measurement}

The hardware of the fluorescence spectrum instrument is shown in Figure 1. The $5 \mathrm{~mW} \mathrm{GaN} \mathrm{based} \mathrm{laser} \mathrm{diode}$ generates an excitation light with the wavelength of 404 $\mathrm{nm}$. The fibreoptic is connected to the laser diode to transmit the light. It consists of a bundle of seven fibre strands: six $400 \mu \mathrm{m}$ illumination fibres surrounding one $400 \mu \mathrm{m}$ reading fibre. The spectrometer measures the intensities of fluorescent light at different wavelengths and transmits the data to the computer.

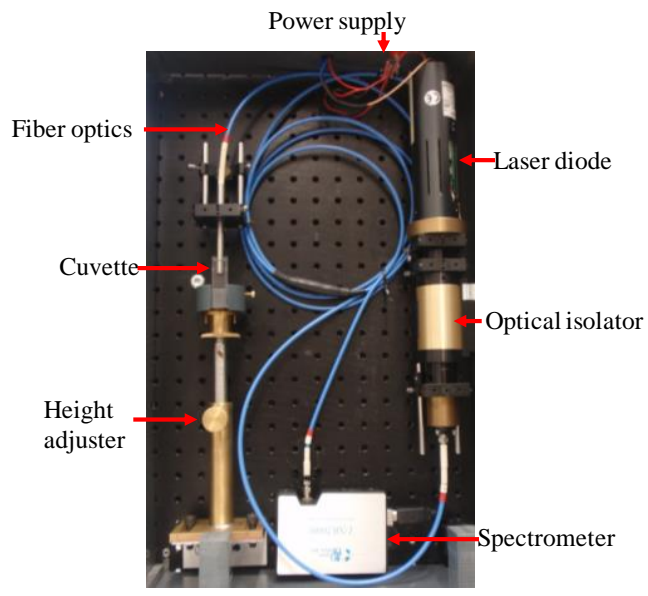

Figure 1 Fluorescence spectrum instrument 
Disposable cuvettes are used for the measurement in case of contaminations between tests. The cuvettes are made from polystyrene and suitable for light from $340 \mathrm{~nm}-800$ $\mathrm{nm}$. The dimension of the cuvettes is $10 \mathrm{~mm} \times 10 \mathrm{~mm} \times 45$ $\mathrm{mm}$. To represent the in-situ conditions, the tip of fibreoptic was immersed into the oil samples.

In preliminary tests, influences of moisture, particle and temperature on spectrum were investigated. It was found that added moisture (up to $50 \mathrm{ppm}$ ), cellulose and copper particles (up to 150000 particles with size larger than 5 $\mu \mathrm{m}$ per $100 \mathrm{ml}$ ) and temperature (up to $80^{\circ} \mathrm{C}$ ) did not change the shape of the spectrum. The spectrum shape is only sensitive to the oil ageing status.

Before fluorescence spectrum measurement, the cuvette with oil sample was vacuumed for 1 minute to remove the bubbles introduced in the sample injection which might influence the spectrum. Since the sensor tip was immersed into the sample, to prevent contamination to the oil sample, the sensor tip was carefully cleaned with fibreless tissues before each measurement.

\section{FLUORESCENCE SPECTRA OF AGED SAMPLES}

The samples were aged for various days under four conditions, including unsealed ageing without copper, unsealed ageing with copper, sealed ageing without copper and sealed ageing with copper, respectively. After the thermal ageing test, their fluorescence spectra were measured and shown in Figure 2.

As can be seen, the typical spectrum is composed of two peaks at $445 \mathrm{~nm}$ and $490 \mathrm{~nm}$ respectively for transformer oil samples thermally aged. When thermal ageing occurs, the spectrum intensity reduces significantly with the ageing time; especially the peak at $445 \mathrm{~nm}$ gradually disappears.

The colours for each individual sample are also shown and the colour change is well in line with the spectrum change: the darker the colour, the smaller the spectrum intensity and the more subtle the first peak at $445 \mathrm{~nm}$.

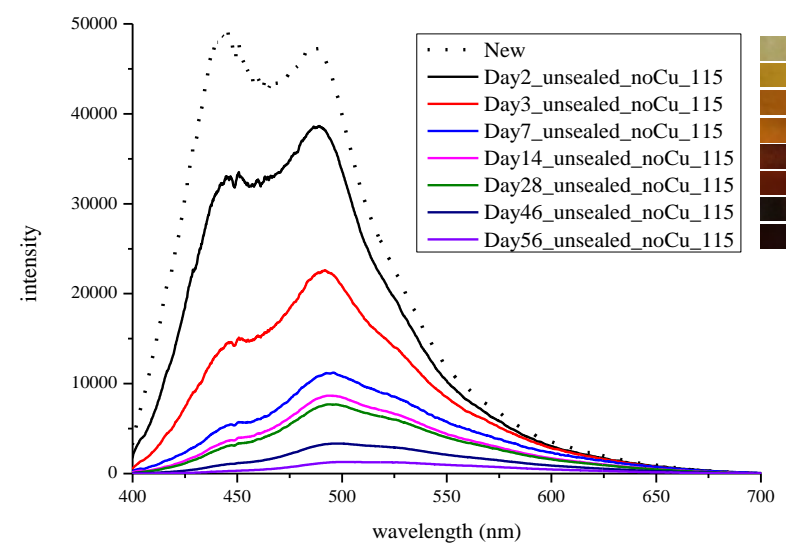

(a) Unsealed ageing without copper at $115^{\circ} \mathrm{C}$

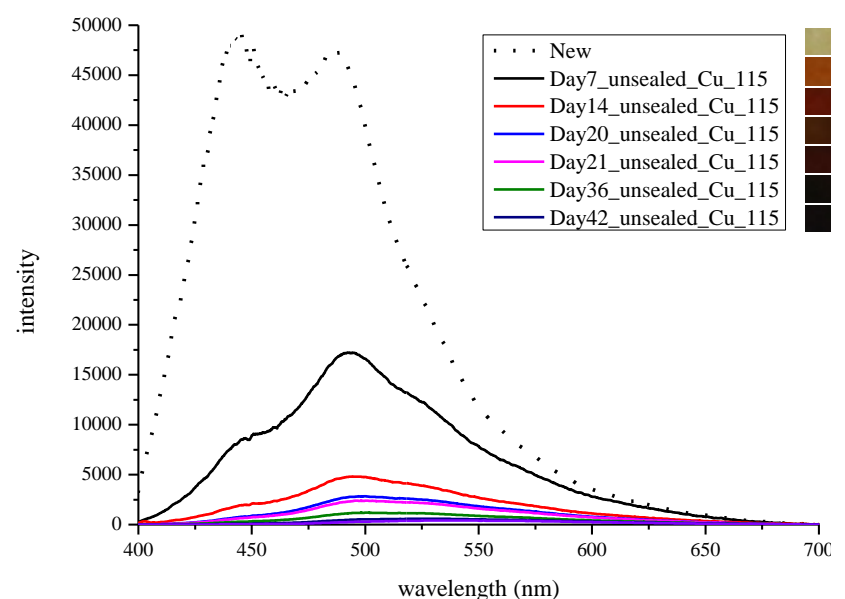

(b) Unsealed ageing with copper at $115^{\circ} \mathrm{C}$

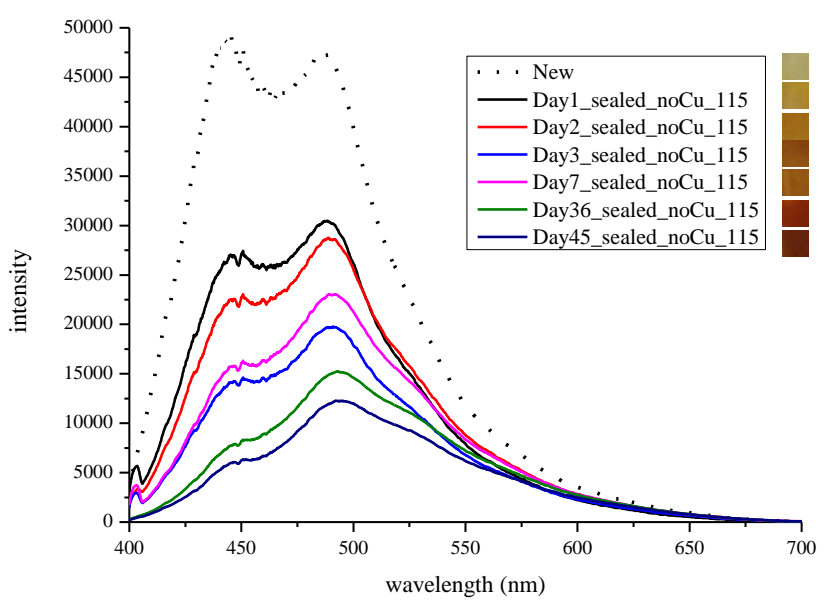

(c) Sealed ageing without copper at $115^{\circ} \mathrm{C}$

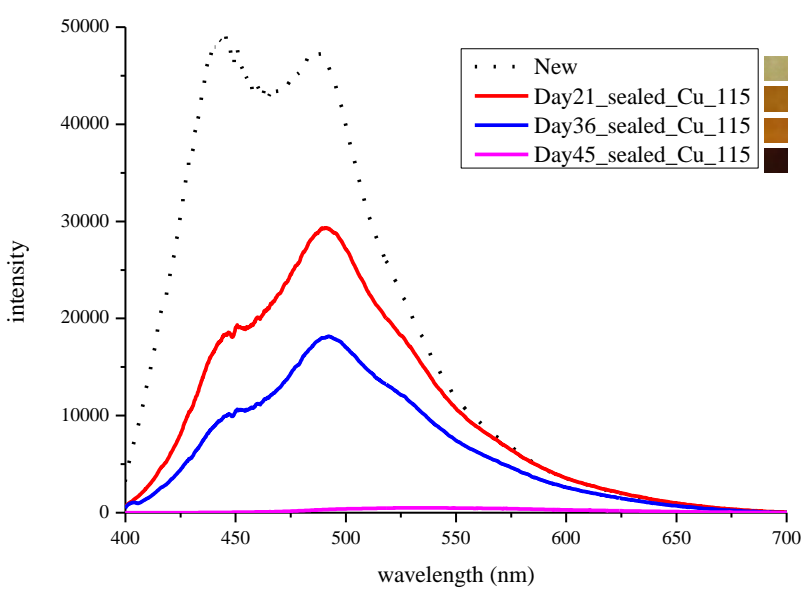

(d) Sealed ageing with copper at $115^{\circ} \mathrm{C}$

Figure 2 Fluorescence spectra and colour of aged oil samples

\section{CORRELATION WITH COLOR INDEX AND TOTAL ACID NUMBER}

Since during ageing, there is a loss of the first peak at 445 $\mathrm{nm}$ when compared to the second peak at $490 \mathrm{~nm}$ in the spectrum intensity (I), it might be possible using this peak 
ratio $\left(\mathrm{I}_{490} / \mathrm{I}_{445}\right)$ to represent ageing status and correlate it with colour index and total acid number.

As can be seen in Figure 3, the ASTM colour scale shows a good exponential relationship with the peak ratio of spectrum, with a determination coefficient $\left(\mathrm{R}^{2}\right)$ of 0.97 . The correlation between peak ratio (PR) and the colour index $(\mathrm{CI})$ can be written as:

$$
P R=0.82+0.27 * \exp (0.44 * C I)
$$

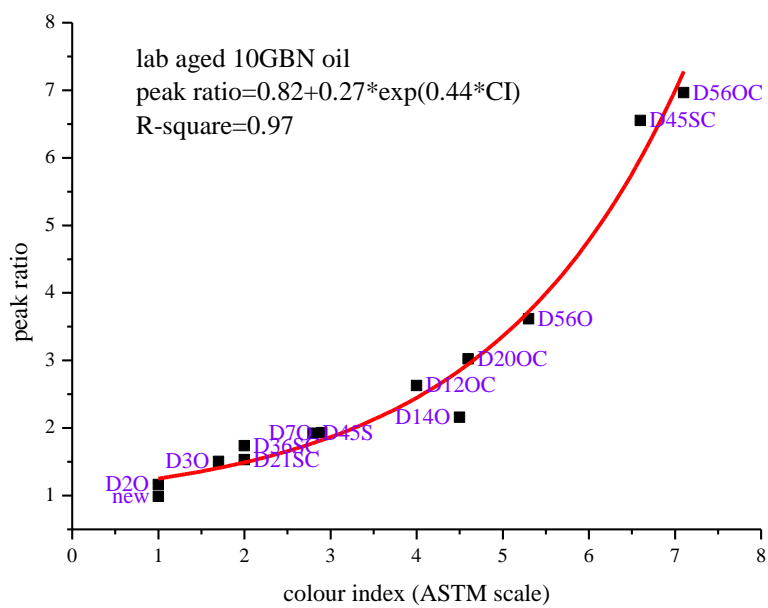

Figure 3 Correlation between peak ratio and colour index (in sample labels, D for day, S for sealed, O for open, C for copper)

As shown in Figure 4, the total acid number shows a good linear relationship with the peak ratio of spectrum, with a determination coefficient $\left(\mathrm{R}^{2}\right)$ of 0.99 . The correlation between peak ratio (PR) and the total acid number (TAN) can be written as:

$$
P R=0.91+9.41 * T A N
$$

The goodness of fitting of colour index and total acid number with the peak ratio in spectrum denotes that the spectrum characteristic represented by the peak ratio can be used to deduce the colour index and total acid number of the sample.

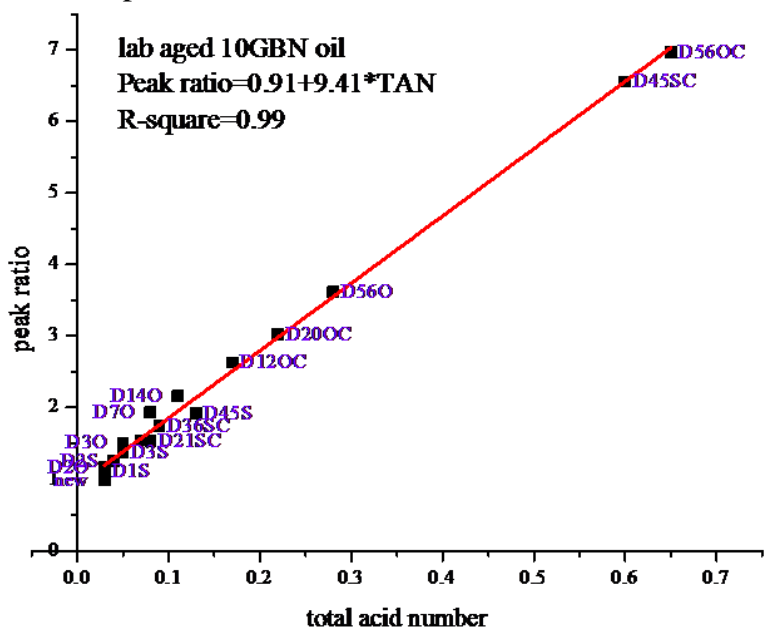

Figure 4 Correlation between peak ratio and total acid number (in sample labels, D for day, $\mathrm{S}$ for sealed, $\mathrm{O}$ for open, $\mathrm{C}$ for copper)

\section{DISCUSSIONS}

The good correlation of peak ratio with colour index and total acid number indicates that peak ratio could be an effective ageing indicator.

As specified in IEC 60422 [14] and widely used by utilities, regarding distribution transformers rated up to $72.5 \mathrm{kV}$, when the total acid number is higher than 0.15 $\mathrm{mg} \mathrm{KOH} / \mathrm{g}$, the deterioration of oil quality can usually be detected, the oil should be more frequently sampled, and the presence of sediment and sludge should be checked; when the total acid number is above $0.30 \mathrm{mg} \mathrm{KOH} / \mathrm{g}$, the abnormal deterioration of oil quality has usually started already, a decision may be required on when to reclaim or replace the oil. Based on the fitted correlation between total acid number and peak ratio of the spectrum, it can be seen that for aged $10 \mathrm{GBN}$, peak ratio of spectrum larger than 2.3 corresponds to total acid number over 0.15 $\mathrm{mg} \mathrm{KOH} / \mathrm{g}$; when the peak ratio larger than 3.7 corresponds to total acid number higher than $0.30 \mathrm{mg}$ $\mathrm{KOH} / \mathrm{g}$.

Due to different oil properties (original colour, inhibited or not, etc), various oil types might behave differently during ageing process. Consequently, the correlation of fluorescence spectral feature with colour index and total acid number might be different, but they can be deduced for each type of oil after laboratory accelerated ageing test was carried for each oil type, so that a fluorescence spectroscopy fingerprinting library can be established and used for the ageing assessment for various types of transformer oils.

By plotting the peak ratios of samples aged for various periods, the ageing pattern of the samples are shown in Figure 5.

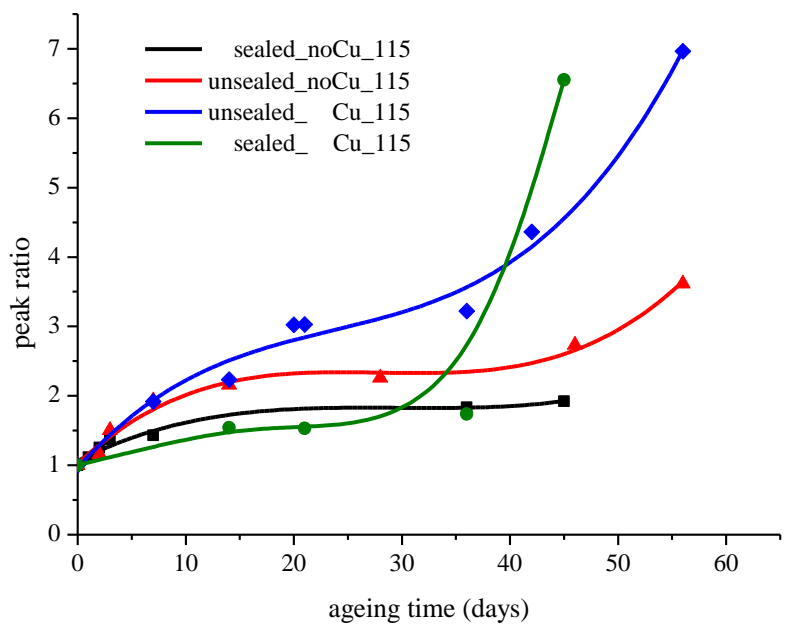

Figure 5 Change of peak ratio with ageing time for various ageing conditions

It can be seen that for samples aged in sealed condition without copper, the ageing rate is the slowest; for the samples aged in open condition together with copper as catalyst, the samples degrade significantly due to oxidation [15]; for the samples aged with copper, but in 
sealed condition, the ageing rate is also obvious, which might be attributed to water which catalyzes the ageing [16], because in sealed ageing, the water generated cannot be evaporated and it will further exacerbate the ageing.

\section{CONCLUSIONS}

In this work, the fluorescence spectroscopy using a lowcost $404 \mathrm{~nm}$ fibre-based GaN semiconductor laser sensor was applied to assess the ageing status of transformer oil thermally aged in laboratory.

It is found that peak ratio (ratio of intensity at $490 \mathrm{~nm}$ and $445 \mathrm{~nm}$ ) of the fluorescence spectrum has good quantitative correlations with traditional ageing indicators, such as colour index and total acid number, which indicates that fluorescence spectrum measurement could be an effective approach for oil ageing assessment. In addition, fluorescence spectrometer is more fielddeployable than colour tintometer and acidity titration system.

Consequently, the fluorescence spectroscopy together with fingerprinting, as a cost-effective online approach, can effectively substitute the colour index and total acid number measurements usually conducted off line in laboratories.

\section{Acknowledgments}

This research project is funded by the Knowledge Transfer Account (KTA) funding of Engineering and Physical Sciences Research Council, UK and Electricity North West, UK under the frame of OFGEM-IFI.

[1] A. D. Hilshey, P. D. H. Hines, and J. R. Dowds, "Estimating the acceleration of transformer aging due to electric vehicle charging," in Power and Energy Society General Meeting, 2011 IEEE, 2011, pp. 1-9.

[2] H. Turker, S. Bacha, D. Chatroux, and A. Hably, "Low-Voltage Transformer Loss-of-Life Assessments for a High Penetration of Plug-In Hybrid Electric Vehicles (PHEVs)," Power Delivery, IEEE Transactions on, vol. 27, pp. 13231331, 2012.

[3] G. Qiuming, S. Midlam-Mohler, V. Marano, and G. Rizzoni, "Study of PEV Charging on Residential Distribution Transformer Life," Smart Grid, IEEE Transactions on, vol. 3, pp. 404-412, 2012.

[4] C. Bessant, L. Ritchie, S. Saini, B. Pahlavanpour, and G. Wilson, "Chemometric Evaluation of Synchronous Scan Fluorescence Spectroscopy for the Determination of Regulatory Conformance and Usage History of Insulation Oils," Appl. Spectrosc., vol. 55, pp. 840-846, 2001.

[5] S. Deepa, R. Sarathi, and A. Mishra, "Synchronous fluorescence and excitation emission characteristics of transformer oil ageing," Elseview-Talanta, vol. 70, pp. 811-817, 2006.
[6] L. Markova, N. Myshkin, C. Ossia, and H. Kong, "Fluorescence Sensor for Characterization of Hydraulic Oil Degradation," Tribology in industry, vol. 29, pp. 33-36, 2007.

[7] J. Vanhanen, M. Rinkio, J. Aumanen, J. KorppiTommola, E. Kolehmainen, T. Kerkkanen, and P. Torma, "Characterization of Used Mineral Oil Condition by Spectroscopic Techniques," Appl. Opt., vol. 43, pp. 4718-4722, 2004.

[8] M. H. Vinas and et al., "Fluorescent probes as mineral oil quality indicators," Pure and Applied Optics: Journal of the European Optical Society Part A, vol. 3, p. 659, 1994.

[9] M. H. Vinas and et al., "Spectroscopic Sensor as a Mineral Oil Indicator," Laser Chem., vol. 12, pp. 65-73, 1992.

[10] T. K. Liang, M. Friedrich, D. Lala, and K. B. Ozanyan, "Portable fluorescence sensor for on-line monitoring of lubricant oils," in Sensors, 2004. Proceedings of IEEE, 2004, pp. 8-11 vol.1.

[11] T. L. Yeo, K. B. Ozanyan, F. Hindle, N. R. J. Poolton, and H. McCann, "Characteristics of Gasoline Fluorescence Using 404-nm SemiConductor Laser Diode Excitation," Appl. Spectrosc., vol. 56, pp. 846-851, 2002.

[12] K. B. Ozanyan, T. L. Yeo, F. P. Hindle, N. R. J. Poolton, H. McCann, and K. L. Tan, "Fiber-based UV laser-diode fluorescence sensor for commercial gasolines," Sensors Journal, IEEE, vol. 4, pp. 681690, 2004.

[13] ASTM-D1500, "Standard test method for ASTM color of petroleum products (ASTM color scale)," American Standards for Testing Materials, 2004.

[14] IEC60422, "Mineral insulating oils in electrical equipment - supervision and maintenance guidance," I. E. Commission, Ed., 2005.

[15] I. Fofana, A. Bouaicha, M. Farzaneh, J. Sabau, D. Bussieres, and E. B. Robertson, "Decay products in the liquid insulation of power transformers," Electric Power Applications, IET, vol. 4, pp. 177184, 2010.

[16] S. Abdi, A. Boubakeur, A. Haddad, and N. Harid, "Influence of Artificial Thermal Aging on Transformer Oil Properties," Electric Power Components and Systems, vol. 39, pp. 1701-1711, 2013/01/02 2011. 